University of Massachusetts Amherst

ScholarWorks@UMass Amherst

\title{
Gender Faultline Strength on Boards of Directors and Strategic Change: The Role of Environmental Conditions
}

\author{
Jie $\mathrm{Wu}$ \\ University of Aberdeen \\ María del Carmen Triana \\ Vanderbilt University \\ Orlando C. Richard \\ University of Massachusetts Amherst \\ Luman $\mathrm{Yu}$ \\ University of Macau
}

Follow this and additional works at: https://scholarworks.umass.edu/management_faculty_pubs

Wu, Jie; del Carmen Triana, María; Richard, Orlando C.; and Yu, Luman, "Gender Faultline Strength on Boards of Directors and Strategic Change: The Role of Environmental Conditions" (2021). Group \& Organization Management. 2.

https://doi.org/10.1177/1059601121992889

This Article is brought to you for free and open access by the Management at ScholarWorks@UMass Amherst. It has been accepted for inclusion in Management Faculty Publication Series by an authorized administrator of ScholarWorks@UMass Amherst. For more information, please contact scholarworks@library.umass.edu. 


\section{Gender Faultline} Strength on Boards of Directors and Strategic Change: The Role of Environmental Conditions
Group \& Organization Management 202I, Vol. 46(3) 564-60I

(C) The Author(s) 2021

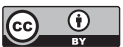

Article reuse guidelines: sagepub.com/journals-permissions DOI: $10.1177 / 1059601121992889$ journals.sagepub.com/home/gom

@SAGE

\author{
Jie $\mathbf{W} \mathbf{u}^{\top} \odot$, María del Carmen \\ Triana ${ }^{2, *}$, Orlando $\mathrm{C}$. \\ Richard $^{3, *}$, and Luman $\mathrm{Yu}^{4}$
}

\begin{abstract}
Drawing on the notion of "faultlines" and the upper echelons perspective, we argue that the gender faultline strength of a board of directors is negatively related to strategic change. More interestingly, while gender faultline strength negatively relates to strategic change under low levels of environmental complexity, environmental dynamism, and environmental munificence, it is positively related to strategic change when environmental complexity, environmental dynamism, and environmental munificence are at high levels. The analyses of panel data of 578I firm-year observations of II7I Chinese firms provide support for the hypotheses.
\end{abstract}

\footnotetext{
'King's College, University of Aberdeen Business School, Aberdeen, UK

${ }^{2}$ Vanderbilt University, Nashville, TN, USA

${ }^{3}$ University of Massachusetts-Amherst, Amherst, MA, USA

${ }^{4}$ University of Macau, Taipa, Macau, China

*Contributed equally

\section{Corresponding Author:}

Jie Wu, King's College, University of Aberdeen Business School, King Street, Aberdeen AB24 5UA, UK.

Email: jie.wu@abdn.ac.uk
} 


\section{Keywords}

board of directors, demographic faultlines, gender faultline strength, strategic change, upper echelons

Why do some organizations initiate strategic change more than others? Addressing this question, upper echelon scholars have linked upper echelon characteristics to strategic change and performance metrics (Deutsch, 2005; Hambrick \& Mason, 1984; Post \& Byron, 2015). More recently, two other lines of research have addressed the topic of top executive team decisionmaking. In the diversity in teams' literature, the argument is often made that team diversity, in particular, top management team diversity is beneficial for innovation by providing informational resources (Van Knippenberg, 2017). In this literature, team diversity is typically characterized by different ideas and perspectives of team members possessing diverse backgrounds, experiences, and knowledge (Nishii, Gotte, \& Raver, 2007; Triana, Miller, \& Trzebiatowski, 2014). Scholars who espouse demographic faultline theory, however, provide a different argument. According to the faultlines in teams' literature advanced by Lau and Murnighan (1998), similarity within and across subgroups within an overall team impacts firm strategic actions and innovation via facilitating or impeding communication between subgroups. To capture demographic similarity or dissimilarity between subgroups within an overall team, Lau and Murnighan (1998) offered the notion of demographic faultlines which emphasizes the need to account for multiple demographic attributes at once. In contrast to single characteristics that describe the demographic diversity of senior management, faultline strength (FLS) captures the similarity within subgroups while considering multiple demographic characteristics simultaneously.

The question thus arises whether it is team diversity or subgroup dynamics related to demographic faultlines that more strongly drive strategic change, which refers to the extent to which a firm modifies its resource allocations to meet changing business needs and sustain a competitive advantage (Hofer \& Schendel, 1978; Miller, 1991; Zhang, 2006). Examining strategic change rather than financial performance enables researchers to look more meticulously at the upper echelons and assess a dependent measure of a more proximal nature (Richard, Wu, Markoczy, \& Chung, 2019). Specifically, concentrating on strategic change provides us the opportunity to craft a parsimonious and tight theoretical model around a critical element of upper echelons' strategic choice and action (Andrevski, Richard, Shaw, \& Ferrier, 2014; Nakauchi \& Wiersema, 2015; Oehmichen, Schrapp, \& Wolff, 2017; Stewart \& Amason, 2017). For this reason, given how much boards of directors vary in demography across firms, a board's demographic composition 
has a notable influence on strategic change (Oehmichen et al., 2017; Triana et al., 2014). Yet, previous research has not provided a clear answer as to what upper echelons' demographic factors play a significant role in influencing strategic change.

The discrepancy between the different arguments about the effects of the top executive team on strategic change that are proposed in the team diversity literature and the faultline literature may be partly due to different foci. Team diversity research tends to concentrate on informational resources that a diverse team would provide, while the faultline research tends to focus on subgroup similarity (cohesion) that impedes informational integration across subgroups within the team. This study draws on the latter line of research (controlling for the former) to consider firm strategic change as a dual problem of similarity within subgroups (which increases the cohesion within subgroups) and cross-subgroup misalignment (CGAI) (which intensifies intragroup conflict) within the team, taking external environmental factors into account. That is, we employ the FLS construct as a fine-grained measure that simultaneously measures the degree of similarity within subgroups (subgroup similarity) and the degree of dissimilarity across gender subgroups (team diversity).

In this study, we focus on gender FLS specifically within the board of directors (BODs) and its influence on strategic change (Finkelstein, Hambrick, \& Cannella, 2009), while accounting for other relevant demographic attributes (e.g., age and educational level) consistent with previous scholarship (Lau \& Murnighan, 1998; Shaw, 2004) because of the following: (a) gender represents a clearly cut attribute which can be observed from group members; (b) a group is split into several subgroups based on one characteristic (such as gender), whether there will be a high level of similarity to other attributes for the subgroups or not; and (c) the number of potential subgroups based on gender alignment within the group. That is, a higher gender FLS indicates that when splitting a group by gender, there will be a high similarity within each subgroup (e.g., the subgroup consisting of women) while less similarity from one subgroup to another (i.e., between the women subgroup and the men subgroup). Below is an example of a group where we assess three demographic attributes: gender, age, and educational level. Gender faultlines split a group into two subgroups, a male subgroup and a female subgroup. If the male subgroup members are under 44 years old with master's degrees, while the female subgroup members are all $\mathrm{PhDs}$ more than 45 years old, the alignment within subgroups is high (high level of similarity) while the alignment between male and female subgroup is low (the two subgroups are different), then we can conclude that the gender FLS in this sample is very high (Chung et al., 2015; Lau \& Murnighan, 1998, 2005). 
We focus on the BODs because research would consider this decisionmaking body as the "supra top management team" whose strategic actions directly impact organizational outcomes (Finkelstein et al., 2009; Post \& Byron, 2015). Gender is equally important as a recent meta-analysis reveals the strategic involvement role that women in BODs play along with men (Post \& Byron, 2015) which we argue has implications for strategic change. However, because organizations are impacted by the industry context in which they operate, the influence of BOD gender FLS on firm outcomes such as strategic change should be influenced by external industry environments (Chadwick, Way, Kerr, \& Thacker, 2013). As suggested by recent faultline scholarship (Cooper, Patel, \& Thatcher, 2014; Richard et al., 2019), we examine three industry-level environmental factors as important boundary conditions (complexity, dynamism, and munificence) that influence the association between board gender FLS and strategic change. We believe such a fine-grained analysis will allow us to detect when gender faultlines might be more or less salient with different implications for its impact on strategic change. In fulfilling this goal, we identified China as an appropriate national setting to examine the effect of gender faultlines and their interaction with these industry-level environmental conditions on firm behavior. Therefore, our empirical analyses were conducted using panel data of 5781 firm-year observations of 1171 manufacturing firms from China characterized by different levels of environmental complexity, environmental dynamism, and environmental munificence.

\section{Theory and Hypotheses}

\section{BOD Gender FLS and its Impact on Strategic Change}

The concept of faultlines was proposed to represent the alignment or misalignment of multiple attributes in a team that can result in subgroup formation (Bezrukova, Jehn, Zanutto, \& Thatcher, 2009; Lau \& Murnighan, 1998). Prior studies have shown that faultlines are a strong predictor of group dynamics because they create the possibility that the group will split into subgroups on various dimensions (Chung et al., 2015). Our approach focuses on gender while simultaneously considering the relevance of other demographic attributes. For instance, suppose that in a six-person team, there are three men and three women. The three men all come from engineering backgrounds, whereas the three women all come from marketing backgrounds. Within the male subgroup, men are all similar with respect to age (mid 60s), nationality (white American), and educational level (bachelor's degrees). In contrast, within the female subgroup, women are similar to each other in terms of age 
(mid 40s), nationality (Asian American), and educational level (master's degrees). In this case, gender FLS would be greater because, in addition to the men/women split on the team, there is homogeneity within each of the subgroups and differences between the subgroups. This implies that members in a subgroup based on a sociocultural attribute, such as gender, share similar social and historical identities. In other words, higher gender FLS indicates that the men are similar to each other in age, nationality, and educational level, and the women are also similar to each other in terms of age, nationality, and educational level, while the men and women have fewer attributes in common as it relates to age, nationality, and educational level.

The aforementioned example highlights the importance of simultaneously assessing the degree of similarity within subgroups and dissimilarity across subgroups. A more precise gender-based faultline has been proposed by Shaw (2004) to consist of two dimensions. The first dimension is subgroup internal alignment which measures the cohesion within subgroups and focuses on how similar members of the same subgroup are (Thatcher, Jehn, \& Zanutto, 2003), while the second dimension is CGAI or the reciprocal of cross-subgroup alignment which measures the extend of difference among members across subgroups (Bezrukova et al., 2009). The degree of faultline is the product of subgroup internal alignment and CGAI. While subgroup internal alignment signifies the extent to which all individuals within a subgroup are similar to one another on all other relevant demographic characteristics (Tuggle, Schnatterly, \& Johnson, 2010), CGAI denotes the extent to which subgroups formed along the faultline diverge (Van Peteghem, Bruynseels, \& Gaeremynck, 2018). Each dimension captures a different aspect of a team. Compared with other attributes (e.g., age, tenure, educational level, functional background, and nationality), gender better satisfies three criteria with respect to the ideal attribute to assess FLS in terms of observability, high level of similarity within subgroups, and high dissimilarity across subgroups.

The academic evidence has demonstrated that demographic faultines conceptually support subgroup dynamics within a team and more accurately predict team outcomes than those found for demographic diversity alone (Bezrukova, Thatcher, \& Jehn, 2007; Thatcher \& Patel, 2012). Thus, it is critical to explore how faultlines within the upper echelons influence strategic decision-making. We propose that BOD gender FLS will negatively affect strategic change for two reasons. First, a high similarity within the female (male) subgroup is likely to increase communication within a subgroup due to similarity attraction (Byrne, 1971), which unfortunately reduces communication across subgroups (Sawyer, Houlette, \& Yeagley, 2006; Van Knippenberg, Dreu, \& Homan, 2004). Although high similarity within gender subgroups has the potential to improve within-subgroup interactions among the women or 
among the men due to similarity-attraction bias (Byrne, 1971), they could also result in reduced communication across the male and female subgroups within the board (Sawyer et al., 2006; Van Knippenberg et al., 2004). Second, a high misalignment between the male versus the female subgroup can result in relationship conflict and tension (Choi \& Sy, 2010; Chung et al., 2015; Lincoln \& Miller, 1979). Conflicts increase difficulty agreeing on a course of action and, therefore, less strategic change and tension is a consequence of conflict or lack of communication between subgroups within the board when gender FLS is strong (Lau \& Murnighan, 1998; Simons \& Peterson, 2000). This is more serious for supra top executives comprising the BODs who rely on their knowledge, largely influenced by their personal characteristics, to process information, and influence firm strategy (Deutsch, 2005; Hambrick \& Mason, 1984). In short, subgroup cohesion intensifies intergroup conflict (Bezrukova et al., 2007; Li \& Hambrick, 2005; Polzer, Crisp, Jarvenpaa, \& Kim, 2006), and CGAI negatively impacts intergroup trust and respect (Cronin, Bezrukova, Weingart, \& Tinsley, 2011; Harrison \& Klein, 2007) and information sharing (Richard et al., 2019; Van Peteghem et al., 2018). This leads to more difficulty making agreements on strategic change with respect to reconfiguring key resource allocations for changing market demands and competitive advantages (Tuggle et al., 2010). Controlling for any BOD diversity effects, we introduce the following gender FLS hypothesis.

Hypothesis 1: BOD gender FLS will be negatively related to strategic change.

Next, we examine three moderating conditions under which the negative effects of BOD FLS on strategic change can be attenuated.

\section{The Moderating Role of Environmental Context}

The environment is one of the most relevant factors that upper echelon cohorts have to contend with (Atinc \& Ocal, 2014; Goll \& Rasheed, 1997), so we find it necessary to not only examine BOD FLS effects on strategic change but also to study this relationship within the environmental context. Upper echelons theory presumes that a firm's executives make strategic choices by using their cognitive filters to process information from the environment (Hambrick \& Mason, 1984). Moreover, executives process information from the environment through their perceptions, interpretations, cognitive schemas, and values, which are shaped by the executives' demographic backgrounds and experiences that represent the knowledge they possess. We draw upon the established typology by Dess and Beard (1984) which presents the following 
three relevant environmental aspects: environmental complexity, environmental dynamism, and environmental munificence. Indeed, firms operating in complex, dynamic, and/or munificent environments require significant input from the BODs (Atinc \& Ocal, 2014). Given the importance of BODs for effective strategic decision-making and changes (Deutsch, 2005), we specifically outline below how each of these three environmental factors independently moderates the negative relationship between BOD gender FLS and strategic change.

Environmental complexity. Viewing environmental complexity from the upper echelons perspective, we define it as the number and diversity of factors (e.g., especially competitors) and components in the macro environment that BODs must deal with in addition to the relationships among external factors they must understand to formulate and implement strategy (Tung, 1979). Possession of high-quality board members becomes critical in a highly competitive, complex environmental context. Decision-making with regards to strategic change in such a context requires high levels of information processing and synchronized coordination among competent board members (and across gender subgroups comprising the faultline) to cope and maintain competitiveness (Dess \& Beard, 1984; Sharfman \& Dean, 1991). When a team (i.e., BOD) operates under high environmental complexity, high collaboration among members is essential because board decisions are then able to benefit from a variety of views and evaluation of various perspectives to arrive at high-quality solutions (Boone, Van Olffen, Van Witteloostuijn, \& de Brabander, 2004; Hambrick \& Mason, 1984; Nyberg \& Ployhart, 2013).

We propose that gender faultlines in BODs likely contribute to strategic change under high environmental complexity as those environments demand information sharing across subgroups and cross-fertilization of ideas (Cooper et al., 2014). Increased environmental complexity stemming from external demands should be matched with a more complex management approach that must coordinate its operations effectively and efficiently (Dervitsiotis, 2012). Furthermore, numerous demands prevalent in complex environments tend to increase the importance and urgency that subgroup contributions are exchanged across gender-based subgroups within the board to facilitate strategic change (Hitt, Hoskisson, Johnson, \& Moesel, 1996). This urgency for information exchange in complex environments emphasizes the need for positive subgroup distinctiveness which will likely mitigate bias and reduce unhealthy interactions between gender-based subgroups within the BOD (Cooper et al., 2014; Van Knippenberg et al., 2004). In other words, when the BOD needs information, subgroup differences should be seen as an opportunity more so than a threat. When BODs operate under high environmental 
complexity, we expect the sharing of relevant information across genderbased subgroups, which results in a more complex team cognitive infrastructure and improved decision-making than BODs operating under low environmental complexity.

Specifically, under conditions of low environmental complexity, subgroups based on strong gender-based faultlines will not likely benefit from crossgender information sharing because the simplicity of the environment will likely reduce communication across gender subgroups and decrease the likelihood of strategic change (Cooper et al., 2014). Research shows that similarity-attraction effects are very strong in teams (Byrne, 1971), whereby people are comfortable interacting with others who are similar to themselves unless the context encourages them to do otherwise. Low environmental complexity is less likely to require gender subgroups comprising the faultline to demonstrate unique contributions to the BOD, and this can result in less strategic change. Thus, controlling for any BOD diversity main effects, we propose the following hypothesis:

Hypothesis 2: The negative relationship between BOD gender FLS and strategic change will be accentuated for firms competing under low environmental complexity but attenuated for firms competing under high environmental complexity.

Environmental dynamism. Environmental dynamism, defined as the magnitude and frequency of environmental change, will also likely influence the strength of the relationship between BOD gender FLS and strategic change (Cooper et al., 2014; Miller, Ogilvie, \& Glick, 2006). High environmental dynamism requires more strategic change in order to meet changing business conditions, and therefore, companies in such contexts could bridge across gender subgroups when a strong faultline exists on the BOD compared to firms operating under low environmental dynamism.

Prior research shows that settings of high environmental dynamism unlock executives' strategic decision-making potential (Yamak, Nielsen, \& EscribaEsteve, 2014) as executives must rely on a broad pool of information to effectively manage the firm in a turbulent context (Gordon, Stewart Jr., Sweo, $\&$ Luker, 2000). We propose that strong gender-based faultlines can provide advantages to boards by presenting useful perspectives that can help firms' executives make strategic changes to remain competitive (Milliken \& Lant, 1991; Yamak et al., 2014). Men and women have differing life experiences and perspectives that can be useful to BODs or executives who need to make decisions to meet the changing business needs of diverse customers. Again, research on team dynamics shows that when differences are seen by the team 
as a source of advantage, diverse teams perform better than when that is not the case (Van Dick, Van Knippenberg, Hägele, Guillaume, \& Brodbeck, 2008). Thus, under high environmental dynamism, all sources of information, including those which can be derived from gender-based faultlines on boards, can be valuable.

Meanwhile, in environments with low environmental dynamism, there should be less need for knowledge exchange to quickly react to changing market conditions. Specifically, there would be less impetus for strategic change and for a BOD with gender faultlines to present various perspectives. This would not be as critical under low environmental dynamism because market conditions change more slowly. As such, we posit that under low environmental dynamism, gender FLS can result in more tension between the subgroups and less information exchange because the firm is not pressed for information and quick change. Research has shown that demographic faultlines are linked with less information exchange on BODs (Tuggle et al., 2010), and that in the absence of an urgent need to collaborate with those who are different than you, the default human tendency is to spend time with those who are similar and familiar (Byrne, 1971). Thus, our prediction is that gender FLS will be associated with less strategic change in contexts of low environmental dynamism than contexts of high environmental dynamism because unique differences between board members may not be required or appreciated in such an environmental context. Controlling for any BOD diversity main effects, we propose:

Hypothesis 3: The negative relationship between BOD gender FLS and strategic change will be accentuated for firms competing under low environmental dynamism but attenuated for firms competing under high environmental dynamism.

Environmental munificence. Finally, we propose that environmental munificence will also serve as a moderator because the abundance or scarcity of resources can have an impact on the degree to which gender FLS influences strategic change. Research shows that demographic faultines are associated with less communication and information processing in BODs (Tuggle et al., 2010). However, regardless of these dynamics, some environments are more conducive to change than others given available resources. Even BODs with the best intentions of making strategic change may not do so if their context is such that they have no resources. To the contrary, resources encourage change, innovation, and competition.

Contexts with low environmental munificence are resource scarce and lack opportunities (Covin \& Slevin, 1989; Park \& Mezias, 2005; Shepherd, Patzelt, 
\& Baron, 2013), while those with high environmental munificence have more abundant growth and access to resources. Under high environmental munificence, members of BODs have more opportunity to recommend business initiatives and directions without severe resource constraints, which would allow for more strategic choices and allocations of resources to pursue business strategy (Bloom \& Michel, 2002; Messersmith, Lee, Guthrie, \& Ji, 2014). High environmental munificence provides BOD members with greater room to present ideas and suggest changes. Because a resource-rich environment is associated with high growth (Dess \& Beard, 1984), gender faultlines on the BOD could lead to more strategic change as members of the upper echelons have more discretion to initiate change and present new ideas based on their interpretation of business conditions (Hambrick \& Finkelstein, 1987; Hambrick \& Mason, 1984). Under munificent environments, a firm's competitors would also be pursuing new strategies for innovation and growth, which would give the upper echelons an impetus to keep up. Under such conditions, the opportunities and resources present under high environmental munificence should facilitate gender-based subgroups on a BOD to make contributions to the strategic decision-making process (Cooper et al., 2014; Van Knippenberg et al., 2004) either within or across subgroups of the BOD. Thus, perspectives shared as a result of BOD gender faultlines will be more likely to result in strategic change than what may happen under low environmental munificence where resources are fewer and firms may not be able to carry out new initiatives even if they wanted to do so.

In a low munificence environment, the context limits strategic choice and directors will have fewer options to suggest change (Karaevli, 2007). In such an environment, strategic change could be particularly important, but without resources, a firm may not be capable of implementing strategic changes anyway. Moreover, research shows that being under strain, such as when a firm is lacking resources or has not been performing well, narrows a team's capacity to think outside the box and process new information (Staw, Sandelands, \& Dutton, 1981). Instead of exploring new opportunities, most teams that are under stress turn to old and tested ways of doing things and jettison tasks that are nice to have since only the most essential functions receive priority (Karau \& Kelly, 1992; Kelly \& Loving, 2004). Teams under stress have also been found to have lower team and individual performance because learning is inhibited (Savelsbergh, Gevers, Heijden, \& Poell, 2012). Therefore, controlling for any BOD diversity main effects, we predict that BODs that possess strong gender faultlines operating in low environmental munificence settings will be related to fewer strategic changes. 
Hypothesis 4: The negative relationship between BOD gender FLS and strategic change will be accentuated for firms competing in low environmental munificence settings but attenuated for firms competing in high environmental munificence settings.

\section{Method}

\section{Data and Sample}

To test the hypotheses, we compiled a panel dataset of Chinese companies publicly listed on the Shanghai stock exchange and Shenzhen stock exchanges. We extracted BOD's demographic characteristics during the 20082018 period from the China Stock Market and Accounting Research (CSMAR) database, a reliable data provider which focuses on Chinese publicly listed companies on the stock exchange, firm-level financial information (e.g., total debt, total assets, advertising expenses, and inventories) from CSMAR's Corporate Financial Statements and Corporate Financial Index Analysis sub-databases, and firm-level variables (e.g., number of employees, foreign ownership, and state ownership) from Stock Market Trading, Corporate Stockholder, Corporate Governance Structure, and Corporate Characters Features sub-databases, respectively, but in the same period. Our final sample included 1175 Chinese firms with 5781 firm-year observations in the period 2008-2018. We lagged all the explanatory variables by 1 year (i.e., independent variables were measured at year $t$ and the dependent variable at year $t+1)$.

\section{Dependent Variable}

Strategic change (time $t+1$ ). Following similar prior studies (Richard et al., 2019; Triana et al., 2014), we measured strategic change of a firm with a composite measure consisting of six critical resource indicators: financial leverage, non-production overhead, advertising intensity, plant and equipment newness, research and development intensity, and inventory level. Specifically, financial leverage is proxied by total debt/total assets; non-production overhead by selling, general, and administrative expenses/net sales; advertising intensity by the ratio of advertising expense divided by net sales, plant and equipment newness by net plant, and equipment/gross plant and equipment; inventory levels by the ratio of inventories divided by net sales; and research and development intensity by the ratio of R\&D expenditures divided by net sales. The information for these variables was extracted from COMPUSTAT. In line with prior studies (Finkelstein \& Hambrick 1990; 
Triana et al., 2014), we first calculated the absolute values of the differences in each index between the prior year and the current year and then calculated the average value and the $S D$ of this difference. Next, we standardized the absolute value of difference for each index. We then averaged the six standardized values to arrive at a composite of strategic change. The mean value of strategic change of the sampled firms is -.00 with a $S D$ of .31 , which is consistent with Zhang (2006).

\section{Independent Variable}

Our independent variable is BOD gender FLS measured at time t. We defined BOD membership by considering senior BOD members (e.g., the chair of the board and key BOD members that directly report to the chair). A board in our sample contains, on average, 10 BOD members yearly. We acquired BOD information from the Listed Firm's Figure Characteristic database in CSMAR. Consistent with our conceptualization, we calculated gender FLS as the product of internal subgroup alignment (IA) and the reciprocal of crosssubgroup alignment $(1-\mathrm{CGAI})$. The general formula is: FLS $=\mathrm{IA} \times(1-$ CGAI). Specifically, we first identify the gender subgroup for each BOD: the value is 1 if gender is man and 2 if gender is woman.

Within each subgroup, it is important to consider other important attributes that can impact the board's strategic decision-making, such as educational level, tenure on the board, nationality, and functional background (Kaczmarek, Kimino, \& Pye, 2012a). Therefore, we calculate other attributes as follows. For the educational level category, the value is 1 if educational level is below associate degree, 2 if educational level is associate degree, 3 if educational level is undergraduate degree, 4 if educational level is master's degree, and 5 if educational level is doctorate degree. For the age category, the value is 1 if age is less than 30 years, 2 if age is equal to or greater than 30 years but less than 44 years, and 3 if age is greater than 44 years. For the tenure category, the value is 1 if tenure on board (measured in months) is less than 12 , 2 if tenure on the board is equal to or greater than 12 but less than 30,3 if tenure on the board is equal to or greater than 30 but less than 60,4 if tenure on the board is equal to or greater than 60 but less than 120 , and 5 if tenure on the board is greater than or equal to 120 . For the BOD functional category, the value is 0 if the functional background is executive and 1 if not. For the nationality category, the value is 1 if nationality is Chinese and 2 if not.

Consistent with prior studies (e.g., Shaw, 2004), we calculated IA by first generating three elements: observed alignment, perfect alignment, and nonalignment. Observed alignment $\left(\mathrm{IA}_{\mathrm{m} / \mathrm{age} / \mathrm{obs}}\right)$ is to measure the distance between actual gender alignment and random distribution in each category 
(e.g., age); perfect alignment $\left(\mathrm{IA}_{\mathrm{m} / \mathrm{age} / \text { perfect }}\right)$ describes the situation where the same gender members belong to the same subgroup category (e.g. all men belong to the same subgroup age $\geq 44$ years); nonalignment ( $\mathrm{IA}_{\mathrm{m} / \mathrm{age} / \text { nonalign }}$ ) describes the situation where people are distributed evenly in each category. The difference between observed alignment and nonalignment is calculated (i.e., $\mathrm{IA}_{\mathrm{m} / \mathrm{age} / \mathrm{obs}}-\mathrm{IA}_{\mathrm{m} / \mathrm{age} / \mathrm{nonalign}}$ ), which is called "alignment difference," and the difference between perfect alignment and nonalignment is also calculated

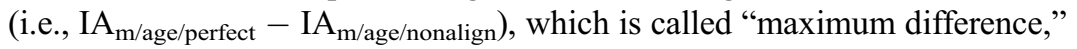
separately for the male and female groups. IA for the male (female) group is then calculated as the ratio of male (female) "alignment difference" divided by male (female) "maximum difference." The overall value of gender IA is: (male IA + female IA) $/ 2$. Taking an example of age as the subgroup category for the male group, the equation to calculate the observed male alignment across age categories $\left(\mathrm{IA}_{\mathrm{m} / \mathrm{age} / \mathrm{obs}}\right)$ could be described as: $\mathrm{IA}_{\mathrm{m} / \mathrm{age} / \mathrm{obs}}=\Sigma\left(\mathrm{O}_{\mathrm{mi}}-\mathrm{E}_{\mathrm{mi}}\right)^{2} / \mathrm{E}_{\mathrm{mi}}$, where $\mathrm{O}_{\mathrm{mi}}$ is the actual observed male number in the i-th category of age category, $\mathrm{E}_{\mathrm{mi}}$ is the expected number of men in the i-th age category if there is random distribution, and $\mathrm{i}=1,2,3$ because we have three categories for age. The only difference between perfect alignment and observed alignment is the value of $\mathrm{O}_{\mathrm{mi}}$. If we assume all men are less than 30 years old, $\mathrm{O}_{\mathrm{m} 1}$ equals the total number of men, and $\mathrm{O}_{\mathrm{m} 2}$ and $\mathrm{O}_{\mathrm{m} 3}$ equal zero. Then, the perfect alignment $\left(\mathrm{IA}_{\mathrm{m} / \mathrm{age} / \mathrm{perfect}}\right)$ for men can be calculated. Similarly, the value of $\mathrm{O}_{\mathrm{mi}}$ for nonalignment is the remainder plus the quotient of the number of men divided by the number of categories. In other words, if there are three men, $\mathrm{O}_{\mathrm{m} 1}=$ $\mathrm{O}_{\mathrm{m} 2}=\mathrm{O}_{\mathrm{m} 3}=3 / 3=1$. But if there are four men, the quotient is one with a remainder of one, which indicates $\mathrm{O}_{\mathrm{m} 1}=2$ and $\mathrm{O}_{\mathrm{m} 2}=\mathrm{O}_{\mathrm{m} 3}=1$. Then, the nonalignment for men $\left(\mathrm{IA}_{\mathrm{m} / \mathrm{age} / \text { nonalign }}\right)$ can be calculated. Next, the maximum difference (MaxDiff) is calculated as MaxDiff $=\mathrm{IA}_{\mathrm{m} / \mathrm{age} / \text { perfect }}-$

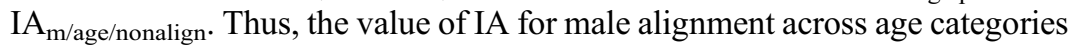
is calculated as $\mathrm{IA}_{\text {males/age }}=\left(\mathrm{IA}_{\mathrm{m} / \mathrm{age} / \mathrm{obs}}-\mathrm{IA}_{\mathrm{m} / \mathrm{age} / \text { nonalign }}\right) / \mathrm{MaxDiff}$. We can get IA for female alignment across age categories $\left(\mathrm{IA}_{\text {females/age }}\right)$ in the same way. Finally, the value of IA for gender across age is calculated as IA gender/age $=$ $(\mathrm{IA}$ males/age $+\mathrm{IA}$ females/age $) / 2$. If we repeat the above process for other attributes (nationality, educational level, functional background, and tenure) and take an average of the total value, we will get an average overall genderbased internal alignment index $\mathrm{IA}_{\text {gender }}=\left(\mathrm{IA}_{\text {gender/age }}+\mathrm{IA}_{\text {gender/nationality }}+\right.$ $\left.\mathrm{IA}_{\text {gender/education }}+\mathrm{IA}_{\text {gender/function }}+\mathrm{IA}_{\text {gender/tenure }}\right) / 5$. The range of IA is from 0 to 1 . A higher value of $\mathrm{IA}_{\text {gender }}$ indicates there is a high level of similarity within the male group and within the female group. If $\mathrm{IA}_{\text {gender }}=1$, it indicates all the men are exactly alike and all women are exactly alike. 
CGAI is described as "the cross-product (CP) approach uses frequency counts of subgroup members in each attribute category and provides an index of the extent to which there are 'matchups' between subgroup members in each category" (Shaw, 2004, p. 74). It has two components: CPs and normalized weight (Wt) for each CP pair. CP calculates the "matchups" (for example, the men older than 44 years old with the women older than 44 years old is a matchup under the three categories of age) between subgroup members using mathematical combination by three steps: (1) to calculate the product of the number of people in each matchup and sum them up, (2) to calculate the number of people in the subgroup which contains the matchup pair, and (3) to calculate $\mathrm{CP}$ for each pair by the ratio of the values in step one divided by the values in step two. Wt indicates the weight for each matchup based on the number of people in the subgroups by three steps: (1) to calculate the product value with the number of people in the subgroups which contains the matchup, that is, the second step to calculate $\mathrm{CP}$ as mentioned above, (2) to sum up the value of step one in all potential subgroups, and (3) calculate $\mathrm{Wt}$ for each pair by the ratio of values in step one divided by the values in step two. For two subcategories such as gender category (men vs. women), the matchups belong to male and female groups, while the potential group subgroups are also the male and female groups, thus $\mathrm{Wt}=1$. After calculating the $\mathrm{CP}$ and $\mathrm{Wt}$ for each pair, we will get CGAI for each pair by the product value of $\mathrm{CP}$ and $\mathrm{Wt}$, that is, $\mathrm{CGAI}_{\text {pair }}=\mathrm{CP} \times \mathrm{Wt}$. Then, we will get CGAI across certain attributes by adding each pair's CGAI together. After repeating the calculation for other attributes (e.g., nationality, educational level, functional background, and tenure), we obtain the values of CGAI for each other attribute and the average overall gender-based cross-subgroup alignment index $\mathrm{CGAI}_{\text {gender }}=\left(\mathrm{CGAI}_{\text {gender/age }}+\mathrm{CGAI}_{\text {gender/nationality }}+\mathrm{CGAI}_{\text {gender/education }}+\right.$ $\mathrm{CGAI}_{\text {gender/function }}+\mathrm{CGAI}_{\text {gender/tenure }} / 5$. The range of CGAI is from 0 to 1 , while 0 represents low alignment across subgroups and 1 represents high alignment across subgroups.

Finally, we get gender-based faultline strength as $\mathrm{FLS}_{\text {gender }}=\mathrm{IA}_{\text {gender }} \times$ $\left(1-\mathrm{CGAI}_{\text {gender }}\right)$. The range of $\mathrm{FLS}_{\text {gender }}$ is from 0 to 1 . Higher values of FLS mean higher values of IA and lower values of CGAI. In other words, if $\mathrm{FLS}_{\text {gender }}=1$, all men are exactly alike and all women are exactly alike, but men and women have no attributes in common. If $\mathrm{FLS}_{\text {gender }}=0$, every man has different age, nationality, educational level, functional background, and tenure, and there is the same situation with all women, but each man shares the same attributes with a woman. The minimum BOD gender FLS in our sample is 0 , and the maximum BOD gender FLS is .48. 


\section{Moderators}

Environmental complexity (time t). Following prior studies (Cooper et al., 2014; Dess \& Beard, 1984), we measured environmental complexity as a fourdimensional measure consisting of the following: (1) the HerfindahlHirschman index (HHI), (2) the four-firm concentration index (Firm-4), (3) the eight-firm concentration index (Firm-8), and (4) establishment diversity (i.e., the number and distribution of small, medium, and large organizations). We derived the calculation of each dimension using the same approach as Tirole (1988) and Cooper et al. (2014) (a) by computing HHI as one minus the sum of the squared market shares for all firms in a 3-digit industry code (i.e., $H H I=1-\sum_{i=1}^{n} a_{i}^{2}$, where $n$ represents number of firms in an industry and $a_{i}$ indicates the firm $i$ 's market share, $i=1, \ldots, n$ ); (b) by computing concentration index of Firm-4 (Firm-8) as 100 minus, the sum of the market shares held by the four (eight) largest competitors. In other words, after every firm in an industry was ranked from the largest market share to the smallest market share and numbered from 1 to $n$, we could get the Firm- 4 and Firm- 8 per the following equations: Firm -4 index $=100-\sum_{1}^{4} a_{i}$; Firm -8 index $=$ $100-\sum_{1}^{48} a_{i}$, where $a_{i}$ indicated the firm i's market share. Higher values of HHI, Firm-4 and Firm-8 mean higher levels of competition; and (c) by computing establishment diversity by the following equation (Cooper et al., 2014): Establishment diversity $=1-\sum_{j}^{m} E_{I}^{2} /\left(\sum_{j}^{m} E_{i}\right)^{2}$, where $E$ is the number of establishments in industry $i$ and $m$ is the number of establishments in small-, medium-, and large-size classes, respectively. The high value of Cronbach alpha (.85) suggests the internal consistency of the four dimensions and good scale reliability for this measure.

Environmental dynamism (time $t$ ). This variable, representing the rate of unpredictable change in a firm's industry, was computed following Keats and Hitt (1988) and Pathak, Hoskisson, and Johnson (2014). We first logtransformed yearly industry gross revenues and then regressed it at time $\mathrm{t}-1$ against time $\mathrm{t}-2, \mathrm{t}-3, \mathrm{t}-4$, and $\mathrm{t}-5$. Through this process we obtained the regression slope's standard error and utilized that value as environmental dynamism (Richard et al., 2019). A large standard error indicates a high level of dynamism.

Environmental munificence (time $t$ ). Environmental munificence is proxied by the industry-year growth rate, which is calculated as industry-wide percentage change in revenues from time $\mathrm{t}-1$ to $\mathrm{t}-2$ (Ferrier, 2001; Richard, Murthi, \& Ismail, 2007). We obtained the industry-level revenues for each year during the study period (2008-2018) and calculated the change of industry revenues 
by subtracting the industry-level revenue at year $\mathrm{t}-1$ from the industry-level revenue at year $t$. The difference was then divided by industry-level revenue at year $\mathrm{t}-1$ to arrive at the percentage of change to proxy industry munificence. The mean value of this variable is .21 with a $S D$ of .23 , which is consistent with Ferrier's study in 2001.

\section{Control Variables}

We included several control variables measured at time $t$ to control for factors which may influence the dependent variable, strategic change. First, we controlled for past strategic change (strategic change at time t). Second, firm size impacts strategic change (Greve, 2011; Hannan \& Freeman, 1984; Jayaraman, Khorana, Nelling, \& Covin, 2000). We thereby controlled for firm size and measured it as the logarithm of the number of employees consistent with Zhang (2006) who found a negative correlation between this specific operationalization of firm size and strategic change. Third, we included firm age as a control variable because previous studies have found that it affects strategic change (Barron, West, \& Hannan, 1994). Following prior studies, we measured firm age as the earliest year between initial public offering year and earliest data accessed year. Then, we also controlled for CEO variables which can influence strategic change, including $C E O$ age and $C E O$ tenure (Shi, Hoskisson, \& Zhang, 2017). We calculated CEO tenure using the period from the time an executive took the CEO position to the present. We also included CEO ownership, which was measured as the ratio of the value of shares held by the CEO divided by the market value of total shares of the firm. Low levels of CEO ownership are important for a more transparent and rigorous corporate governance because BOD members may prefer to work closely regardless of the presence of a faultline when they have less power relative to the CEO resulting in weaker faultlines with strong implications for strategic change. We extracted the information about the value of shares held by the CEO at the end of the reporting period from the Corporate Governance sub-database of CSMAR and the market value of the firm from the Stock Trading sub-database.

We also controlled for BOD size and several types of BOD heterogeneity (BOD nationality, age, educational level, functional background, and tenure heterogeneity). ${ }^{1}$ BOD size was measured as the number of board members for the firm each year. We extracted BOD attribute information from the general information of Listed Firm's Figure Characteristic in CSMAR. Following prior studies (Triana et al., 2014), we adopted Blau's index to calculate BOD nationality heterogeneity, BOD educational level heterogeneity, and BOD functional background heterogeneity, which is specified as: $1-\sum \mathrm{p}_{\mathrm{i}}{ }^{2}$, where $\mathrm{p}_{\mathrm{i}}$ 
is the proportion of subgroup members in the entire group number of members with each attribute in a BOD. For the continuous measures, BOD age heterogeneity and BOD tenure heterogeneity, we used the coefficient of variation. Moreover, we controlled potential year effects (2008-2018) by generating year dummy variables and included them in the analyses. Finally, because the sampled firms come from 29 industries from $\mathrm{C} 13$ to $\mathrm{C} 42$ in the manufacturing industry at the 3-digit level, we generated a set of industry dummy variables and included them in the analyses.

\section{Econometric Model}

Our panel data are in the structure of yearly repeated observations per firm over the period, which makes ordinary regression models inappropriate and requires an appropriate econometric model. The fixed and random effects are the most suitable models for analyzing the panel data because they account for the unobserved effects and partially solve for an endogeneity concern. To decide whether a fixed- or random-effects model was more appropriate, we conducted Hausman's (1978) specification test, and the results of the Hausman test were significant $\left(\chi^{2}=1265.66, p=.000\right)$, suggesting that a fixed-effects model is preferred. Thus, we used the fixed- effect model in the analyses.

One concern might be that time-specific factors such as government interventions or economic downturns might affect strategic change-an omitted-variable issue (Certo \& Semadeni, 2006). To address this concern, we included a set of year dummy variables in our panel data model with a large $N$ (number of firms) and a relatively small $T$ (time periods), which has proved to be useful in reducing the influence of contemporaneous correlation (Baltagi, 2008). Another concern is strategic change may affect BOD gender faultline characteristics. For example, a firm with high strategic change may be more inclined to add BOD members who differ from the current directors, and thus, BOD faultlines might be partially affected. To address this concern, we lagged the dependent variable 1 year after all the explanatory variables to account for reverse-causality effects. That is, in testing for the main effects of BOD gender FLS on strategic change, we regressed the dependent variable, strategic change at year $\mathrm{t}+1$ (e.g., 2009), on the independent variables (e.g., BOD gender FLS) at year t (e.g., 2008).

\section{Correcting for Endogeneity}

The endogeneity problem arises if the true value of independent variables that correlate to both the dependent variable and one or more independent 
variables is hidden. To address this concern, we constructed the independent variables from annual reports and obtained top management team (TMT) information from CSMAR, so the errors-in-variables issue is less likely. As noted above, we controlled several alternative explanatory variables in the analyses to eliminate the omitted-variable bias. As such, our focus is to tackle the simultaneous causality concern regarding plausible effects from performance to BOD gender faultlines. That is, BOD gender faultlines could be endogenous to strategic change.

We correct for endogeneity related to contemporaneous reverse causality in several ways. First, as noted above, we lagged the independent variable at time $\mathrm{t}-1$ (i.e., the independent variables at year $\mathrm{t}-1$ and the dependent variable at year $t$ ) to reduce the possibility of reverse causality. Second, we assessed the exogeneity of BOD gender faultlines by conducting the Durbin-Wu-Hausman test (note: $\mathrm{H}_{0}$ : the BOD gender faultlines are exogenous). The syntax in Stata is -xtivreg2-. The results with nonsignificant chi-square tests of the Durbin-Wu-Hausman test (chi-square $=.57, p=.450$ ) cannot reject H0. This suggests that BOD gender faultlines are exogenous and that the subsequent estimates are unbiased and can be reported.

To alleviate any endogeneity concerns and to make a conservative estimation, we deployed two-stage least squares (2SLS) regression analyses. In the first-stage regression analyses, we included the instrumental variables to predict gender faultlines strength. Two instrumental variables have been identified as relevant and valid instruments by prior faultine studies (Cooper et al., 2014): the proportion of male directors on the board (because a high proportion of men on a board imply that the gender FLS may result in a relatively weak internal alignment compared with a gender-balanced board, thus having weak FLS) and board size (because a large board size is important for developing more transparent and rigorous corporate governance structures and BOD members of a large board size may need to work closely regardless of the presence of faultlines, resulting in weaker faultlines, with strong implications for strategic change). The estimated results are used to generate the predicted value, which was included in the second-stage regression analyses to take account of the endogeneity effect in the analyses.

\section{Results}

Table 1 shows the correlations and descriptive statistics. The variance inflation factor (VIF) values are all within an acceptable range (Aiken \& West, 1991; Tabachnick \& Fidell, 2001), with a maximum VIF value of 1.65, a minimum VIF value of 1.02, and a mean VIF value of 1.20. In addition, looking at the correlations between variables suggests that multicollinearity is not a notable 


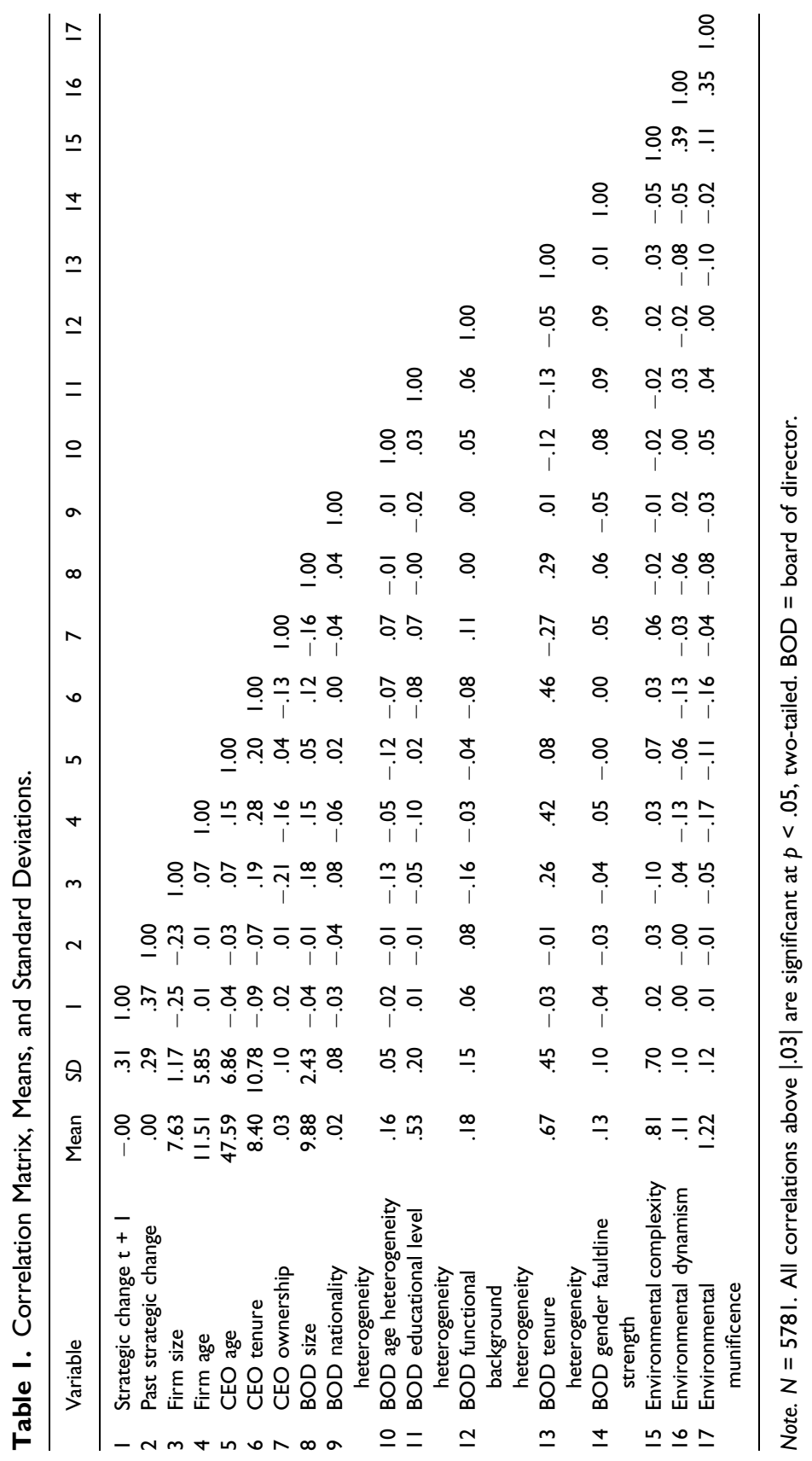


Table 2. Fixed-Effects Regression Models Predicting Strategic Change.

\begin{tabular}{|c|c|c|c|c|c|c|}
\hline & \multicolumn{6}{|c|}{ Strategic change } \\
\hline & \multicolumn{3}{|c|}{ Model I } & \multicolumn{3}{|c|}{ Model 2} \\
\hline & B & $S E$ & $\beta$ & B & SE & $\beta$ \\
\hline Constant & $.49 * * *$ & .01 & & $.49 * * *$ & .01 & \\
\hline Year dummy & Included & & & Included & & \\
\hline Industry dummy & Included & & & Included & & \\
\hline Past strategic change & .01 & .01 & .00 & $.01^{*}$ & .01 & .00 \\
\hline Firm size & $-.08^{* * *}$ & .00 & -.91 & $-.08 * * *$ & .00 & -.91 \\
\hline Firm age & $-.00^{*}$ & .00 & -.02 & $-.00^{*}$ & .00 & -.02 \\
\hline CEO age & .00 & .00 & .00 & .00 & .00 & .00 \\
\hline CEO tenure & $-.00^{*}$ & .00 & -.02 & $-.00^{*}$ & .00 & .00 \\
\hline CEO ownership & $-.0 \mathrm{I}^{* *}$ & .00 & -.01 & $-.0 \mathrm{I}^{* * *}$ & .00 & -.01 \\
\hline BOD size & .00 & .00 & .00 & .00 & .00 & .00 \\
\hline BOD nationality heterogeneity & $-.23 * * *$ & .00 & -.16 & $-.23 * * *$ & .00 & -.16 \\
\hline BOD age heterogeneity & $.04^{* * *}$ & .00 & .04 & $.04 * * *$ & .00 & .04 \\
\hline BOD educational level heterogeneity & $.10^{* * *}$ & .00 & .26 & $.10 * * *$ & .00 & .26 \\
\hline $\begin{array}{l}\text { BOD functional background } \\
\text { heterogeneity }\end{array}$ & $.03 * * *$ & .00 & .03 & $.03^{* * *}$ & .00 & .03 \\
\hline BOD tenure heterogeneity & -.01 & .01 & -.02 & -.01 & .01 & -.01 \\
\hline Inverse Mill's ratio & .02 & .02 & .03 & .02 & .02 & .02 \\
\hline BOD gender faultline strength & $-.20 * * *$ & .01 & -.12 & $-.20 * * *$ & .01 & -.12 \\
\hline Environmental complexity (A) & $.04^{* * *}$ & .01 & .04 & $.04^{* * *}$ & .01 & .04 \\
\hline Environmental dynamism (B) & $.80^{*}$ & .39 & .02 & .29 & .38 & .01 \\
\hline Environmental munificence (C) & .02 & .01 & .01 & $.03^{*}$ & .01 & .02 \\
\hline BOD gender faultline strength $\times A$ & & & & $.21^{* * *}$ & .04 & .01 \\
\hline BOD gender faultline strength $\times$ B & & & & $4.15^{*}$ & 1.82 & .01 \\
\hline BOD gender faultline strength $\times C$ & & & & $1.06 * * *$ & .05 & .05 \\
\hline Log-likelihood & \multicolumn{3}{|c|}{$21,707.22$} & \multicolumn{3}{|c|}{$22,086.42$} \\
\hline Akaike information criteria & \multicolumn{3}{|c|}{$-43,220.43$} & \multicolumn{3}{|c|}{$-43,972.85$} \\
\hline F-score (dfI, df2) & \multicolumn{3}{|c|}{2421.19} & \multicolumn{2}{|c|}{2564.70} & $(99,568 I)^{* * *}$ \\
\hline$\Delta$ F-score $(\mathrm{dfl}, \mathrm{df2})$ & \multicolumn{2}{|c|}{$(96,5684)^{* * *}$} & & $|43.5|$ & $(99,56$ & 681) \\
\hline $\mathrm{R}^{2}$ & \multicolumn{3}{|c|}{.9637} & \multicolumn{3}{|c|}{.9667} \\
\hline$\Delta \mathrm{R}^{2}$ & & & & & & \\
\hline Prob > chi2 & \multicolumn{3}{|c|}{.000} & \multicolumn{3}{|c|}{.000} \\
\hline
\end{tabular}

Note. $N=578 \mathrm{I}$. Unstandardized B-weights, standard errors, and standardized beta-weights are reported. ${ }^{* *} p<.00 \mathrm{I},{ }^{* *} p<.0 \mathrm{I},{ }^{*} p<.05$ (two-tailed tests). BOD $=$ board of director.

problem. BOD gender FLS and the three moderators were mean centered before creating the interaction terms (Aiken \& West, 1991).

Table 2 reports the results including the interaction terms with three environmental context moderators. Unstandardized B-weights, standard errors, 
and standardized beta-weights are also reported in the table. In our study, we first use the Akaike information criterion (AIC) to evaluate the goodness of fit of our models: the smaller the AIC, the better goodness of fit for a model. As shown in Table 2 (see the bottom), the AIC of Model 2 is smaller than that of Model $1\left(\mathrm{AIC}_{\text {model 2 }}=-43,972.85<\mathrm{AIC}_{\text {model 1 }}=-43,220.43\right)$, indicating that Model 2 including three interactions increases the goodness of fit over Model 1. Furthermore, we use the log-likelihood to evaluate the goodness of fit of our models: the larger the log-likelihood, the better the goodness of fit of a model. As shown, the log-likelihood of Model 2 is larger than that of Model 1 (log-likelihood $_{\text {model } 2}=22,086.42>\log$-likelihood model $\left.1_{1}=21,707.22\right)$, indicating that Model 2 including three interactions increases the goodness of fit over Model 1. In short, the results evaluating the model based on the AIC and log-likelihood are consistent. In our study, we use R-squared as the measure of the overall effect size for the entire model. The effect size for the main effects model is .964, and the effect size for the interaction effects model is .967. Moreover, we use Eta-squared as the measure of the effect size for regression coefficients. We will discuss the effect size of regression coefficients in the following section. These results provide support that our independent variable and moderators strongly improve the goodness of fit of the baseline model.

Hypothesis 1 posits that BOD gender FLS is negatively related to strategic change. As shown in Model 1 of Table 2, the coefficient of BOD gender FLS is negative and significant (B-weight $=-.20, p=.000$ ) with a $95 \%$ confidence interval $[-.21,-.19]$, and the effect size for BOD gender FLS is .123. These results support Hypothesis 1. Hypothesis 2 posits that the negative relationship between BOD gender FLS and strategic change will be accentuated (attenuated) for firms competing in a low environmental complexity (high environmental complexity) setting. As shown in Model 2 of Table 2, the coefficient of the interaction term, BOD gender FLS $\times$ environmental complexity, is positive and significant (B-weight $=.21, p=.000$ ) with a $95 \%$ confidence interval $[.13, .29]$. The effect size (i.e., Eta-squared) for the interaction term of BOD gender FLS and environmental complexity is .003. Following Aiken and West (1991), we provided a visual of this interaction which was plotted at plus and minus one $S D$ for the moderator, environmental complexity, in Figure 1. The horizontal axis represents BOD gender FLS and the vertical axis represents the level of strategic change. The solid line represents the effect of BOD gender FLS on strategic change under low levels of environmental complexity, and the dashed line represents the effect of BOD gender FLS on strategic change under high levels of environmental complexity conditions. Figure 1 shows that the association between BOD gender FLS and strategic change is negative under low environmental complexity, but 


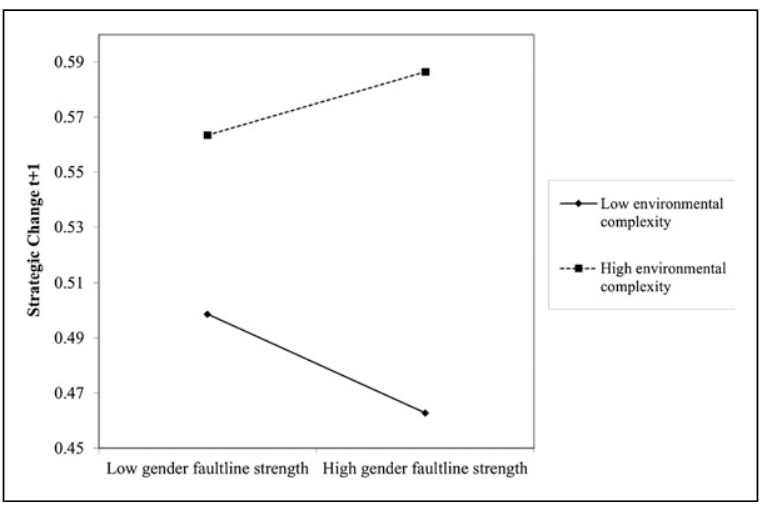

Figure I. Interactive effect of board of director gender faultline strength and environmental complexity predicting strategic change.

that effect is attenuated and, in fact, has a positive slope under high environmental complexity. These results support Hypothesis 2 .

Model 2 in Table 2 reports the results testing Hypothesis 3, including the interaction with environmental dynamism. Hypothesis 3 posits the negative relationship between BOD gender FLS and strategic change will be accentuated (attenuated) for firms competing in a low environmental dynamism (high environmental dynamism) setting. As shown in Model 2 of Table 2, the coefficient of the interaction term, BOD gender FLS $\times$ environmental dynamism, is positive and significant (B-weight $=4.15, p=.023$ ) with a $95 \%$ confidence interval $[.58,7.71]$. The effect size (i.e., Eta-squared) for the interaction term of BOD gender FLS and environmental dynamism is .001. We provided a plot of the interaction in Figure 2. Figure 2 shows that the association between BOD gender FLS and strategic change is negative under low environmental dynamism, but that relationship is attenuated and has a positive slope under high environmental dynamism. These results support Hypothesis 3.

Model 2 in Table 2 reports the results testing Hypothesis 4, including the interaction with environmental munificence. Hypothesis 4 posits that the negative relationship between BOD gender FLS and strategic change will be accentuated (attenuated) for firms competing in a low environmental munificence (high environmental munificence) context. As shown in Model 2 of Table 2, the coefficient of the interaction term, BOD gender FLS $\times$ environmental munificence, is positive and significant $(\mathrm{B}$-weight $=1.06, p=.000)$ with a $95 \%$ confidence interval $[.95,1.17]$. The effect size (i.e., Eta-Squared) for the interaction term of BOD gender FLS and environmental munificence is .042 . Figure 3 shows that the association between BOD gender FLS and 


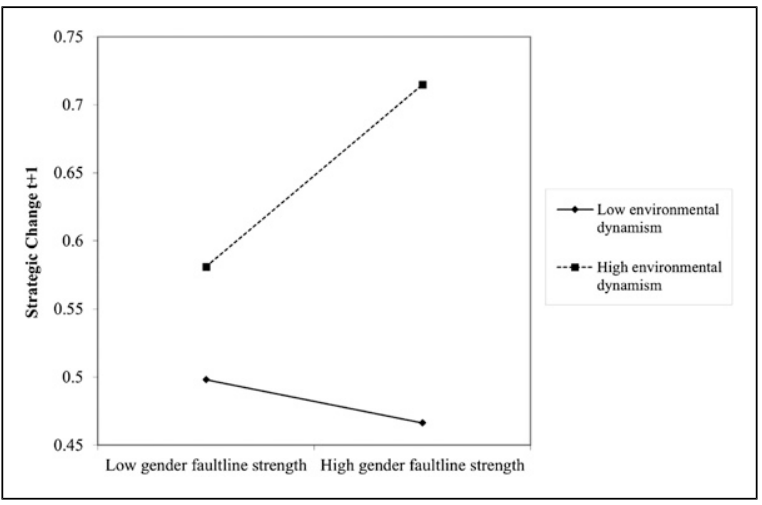

Figure 2. Interactive effect of board of director gender faultline strength and environmental dynamism predicting strategic change.

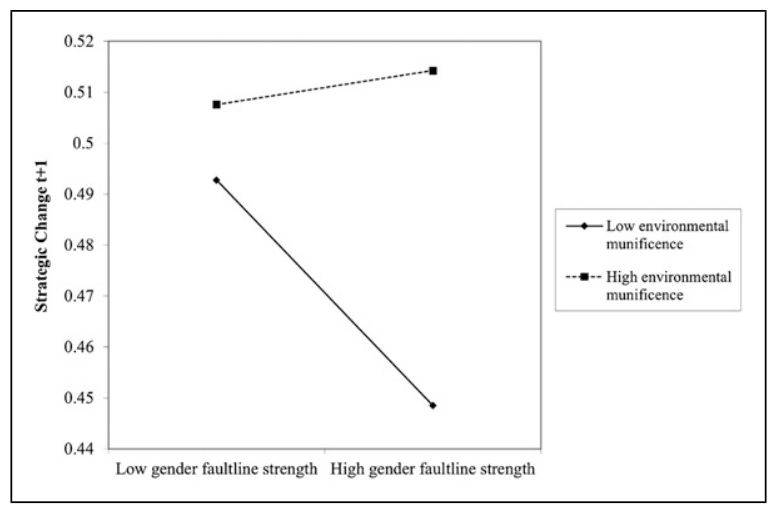

Figure 3. Interactive effect of board of director gender faultline strength and environmental munificence predicting strategic change.

strategic change is negative under low environmental munificence, but that relationship is attenuated and has a positive slope under high environmental munificence. These results provide support for Hypothesis 4.

\section{Supplemental Analyses}

We conducted various analyses to check the sensitivity of the results. ${ }^{2}$ One concern is the BOD heterogeneity variables could be part of the faultline 
measure that may affect the significant relationship between gender FLS and the outcomes of interest as well as the interaction effect results. To address this concern, we have conducted the analyses by including and excluding demographic heterogeneity controls and rerunning the analyses separately. First, we reran the analyses with the models including six BOD heterogeneity variables (BOD gender heterogeneity, nationality heterogeneity, age heterogeneity, educational level heterogeneity, functional background heterogeneity, and tenure heterogeneity). Next, we excluded BOD heterogeneity variables from the regression models and reran the analyses. All the results are consistent with previous findings: the effect of gender FLS is statistically significant; the interaction terms: BOD gender FLS $\times$ environmental complexity, BOD gender FLS $\times$ environmental dynamism, and BOD gender FLS $\times$ environmental munificence are positive and statistically significant. These results together suggest that the effect of BOD gender FLS on strategic change and the moderating of environmental contexts is robust across the analyses including and excluding the analyses suggest that these results are robust and provide additional supports for our hypotheses.

Another concern could be that given that many of the firms in the database are from the same sector; it is possible that faultlines and strategic changes could be different between industries but similar (if not very similar) within industries. To address this concern, we implement various ways of conducting multilevel analysis and found consistent results. Ultimately, accounting for industry differences using 29 dummy coded variables helps to alleviate most of this concern, but we conducted additional tests nonetheless. Specifically, we first use a fixed-effects model with cluster-robust standard errors for panels nested within industry. Second, we reran the analysis simply clustering the data by industry. Moreover, we use two-level fixed-effects regression by industry with robust standard errors to rerun the models. All the results show that the effect of gender FLS is statistically significant; the three interaction terms, BOD gender FLS $\times$ environmental complexity, BOD gender FLS $\times$ environmental dynamism, and BOD gender FLS $\times$ environmental munificence, are all positive and statistically significant. In short, the results are consistent across various multilevel analyses and provide additional support for the hypotheses. ${ }^{3}$

\section{Discussion}

\section{Theoretical Implications}

The impact of upper echelons demography, which varies substantially across firms, is a key factor to consider when investigating the determinants of 
strategic change (Triana et al., 2014; Zhang, 2006). This study supports and extends upper echelons theory (Hambrick \& Mason, 1984) by showing that BOD gender FLS negatively influences the level of strategic change. Upper echelons theory proposes that top executives utilize their own filters to assess environmental stimuli, interpret the environment, and make strategic decisions (Hambrick \& Mason, 1984). This information-filtering process involving the top executives using their cognitive base, values, selective perception, and interpretation to make strategic choices tends to focus on characteristics including "age, tenure in the organization, functional background, educational level, socioeconomic roots, and financial position." Hambrick and Mason (1984, p. 196). However, most upper echelon scholars have remained agnostic with respect to subgroup dynamics through which information sharing is facilitated or inhibited across subgroups. This study offers a more detailed look at the effect of top executives on firm strategy and behaviors by considering subgroup dynamics and cross-group misalignment as well as various environmental situations. Moreover, the findings of this study introduce three important boundary conditions (environmental complexity, environmental dynamism, and environmental munificence) on the assertion by upper echelons theory that the characteristics of the board influence the firm's outcomes such as strategic change. Characteristics of leaders in the upper echelons matter, as the theory purports, but they are much more likely to result in strategic change in some conditions than others. This study has shed light on this fact.

Second, this study contributes to the faultlines research by investigating the effect of gender FLS on strategic change and its boundary conditions. Although prior studies have shown that demographic faultlines explain subgroup dynamics more precisely and empirically reveal stronger effects on team outcomes than demographic diversity (Bezrukova et al., 2007), less is known about how gender faultlines of the BOD impact strategic change (Chung et al., 2015; Meyer \& Glenz, 2013). The finding in this study that BOD gender FLS is negatively associated with strategic change under low levels of high environmental complexity, environmental dynamism, and environmental munificence but is positively associated with strategic change under high environmental complexity, environmental dynamism, and environmental munificence provides some evidence for the contention that faultline research considering external environments could benefit from a richer conceptualization of boundary conditions. The implication is that faultline scholars could provide a more complete account of the role of faultlines at the top executive level in organizations for strategic change by considering BOD gender faultlines as well as various types of external environmental conditions. 
Third, this study contributes to the team diversity literature by adopting a demographic faultline lens to account for the alignment of multiple characteristics within and across gender-based subgroups in a BOD to reveal a more nuanced and comprehensive understanding of how team diversity on the BODs impacts strategic change. Existing team diversity research has paid less attention to the importance of team diversity for strategic change and has remained largely ambiguous with respect to the role of the external environments (Richard et al., 2019). As a result, it is still unclear in the team diversity literature whether or not team diversity stunts strategic change as some reviews of the literature show (Menz, 2012; Williams \& O'Reilly 1998), or bolsters it, as other more optimistic perspectives of diversity would predict (Cox \& Blake, 1991; Richard \& Shelor, 2002). The findings of this study showing the effect of the faultline consisting of two dimensions (subgroup cohesion and intragroup misalignment, through which strategic change is determined) would not have been elucidated if either dimension was considered alone. The implication is that studies of BOD faultlines on strategic change could provide a more complete account by conceptualizing team diversity in the upper echelons in a more nuanced way, rather than straightforward as other studies have done.

Fourth, this study contributes to leadership research. The past few decades have witnessed a very slow increase in women within US boards, with some saying the pace is akin to running in place (2020 Women on Boards, 2017; Tinsley, Wade, Main, \& O'Reilly, 2017). Most gains made by women on boards have come from countries other than China and the United States, where quotas have been implemented for women's representation (Adams, 2016). Meanwhile, women have slowly reached a few senior leadership positions in organizations around the world (for the United States, see Maume Jr., 2004; Morrison, White, \& Van Velsor, 1992; Smith \& Parrotta, 2018; for China, see Wall Street Journal, 2012). Recent scholarship has begun to examine how women's presence together with men in the upper echelons impacts firm strategy and firm outcomes (Cumming, Leung, \& Rui, 2015; Jeong \& Harrison, 2017; Post \& Byron, 2015; Triana et al., 2014). Given that most leadership research has been conducted in the United States, this study bridges the scholarly efforts by analyzing panel data of manufacturing firms in China, the second largest economy in the world (Richard et al., 2019). The findings of this study provide evidence to support previous research linking BODs to firm strategy and place much emphasis on upper echelons gender faultlines in organizations, an area that is relatively less examined in the strategic management and corporate governance literatures than simpler measures of gender diversity among corporate elites. 


\section{Practical Implications}

Our findings from Chinese BODs further challenge the notion that visible diversity introduces a problem to be managed rather than a resource to be utilized to gain a competitive advantage as Cox and Blake (1991) suggested. The findings of this study show that board gender FLS has a negative effect on strategic change under low levels of environmental complexity, dynamism, and munificence, and the relationship between board gender FLS and strategic change is positive when environmental complexity, dynamism, and munificence are high. This sends an interesting message to practitioners that under different situations with environmental complexity, environmental dynamism, and environmental munificence, such diversity of perspectives brought about by board gender faultlines can make a difference in initiating strategic changes. It will be wise for a firm to configure and reconfigure the members of the top executive team taking account of different levels of environmental complexity, dynamism, and munificence because doing so helps it to maximum the value of a diverse team consisting of multiple subgroups by avoiding any negative effect and reaping its benefits for strategic change and behavior.

More generally, the findings also send an important message to managers in other contexts with similar levels of environmental dynamics, environmental complexity, and environmental munificence that a strong gender faultline could be advantageous, at least insofar as it can initiate strategic change which helps firms meet shifting market conditions. This implies that both men and women should be on the board to strengthen gender faultlines that are positively related to strategic change in times when environmental complexity, dynamism, and munificence are high, and the firm can use differing perspectives the most. This obviously requires both men and women to be nominated and selected for board positions (Kaczmarek, Kimino, \& Pye, 2012b). To be clear, we do make assumptions about how these strategic changes will impact financial performance. We emphasize that the outcome of strategic change for a firm's financial performance may be positive, negative, or neutral. Some studies have reported a positive effect of strategic change on firm performance (Barr, Stimpert, \& Huff, 1992; Kraatz \& Zajac, 2001), while others have found a negative relationship (Mitchell, Shaver, \& Yeung, 1992), and still others show no relationship (Zajac \& Kraatz, 1993). Strategic changes do not always have beneficial impacts on firms, although firms make them with that intention. More importantly, strategic change or lack thereof can be an important goal in and of itself. 


\section{Limitations and Future Research Directions}

Like many other studies, this study is not perfect which in turn points out future research directions. First, this study focuses on gender FLS on the BOD and its impact on strategic change, partly due to the fact that the gender attribute better satisfies the criteria of the faultline measure with less confusion, as opposed to other types of attributes. Future research may also examine other types of faultlines on BODs. Upper echelons theory suggests that all of a manager's demographic characteristics can be used to shape their preferences and cognitions (Hambrick \& Mason, 1984).

Another limitation which is also related to our faultline measure is that the Shaw (2004) faultline measure requires that we take some continuous variables such as age and tenure and categorize them in order to create the faultine measure. Categorizing variables that are normally continuous discards valuable information. However, as part of the faultline measure, members of the board are placed into discrete groups. For example, if we were dividing the students in a class based on height and weight, we would need to determine cut points where we call some students short versus tall and some students almost any performance heavy versus light. If we used a continuous measure of height and weight (or age and tenure as used in this study), instead of some arbitrary cut point, we would end up with a number of subgroups that are equal to the number of students in each category. Therefore, we acknowledge that variance is lost for the age and tenure variables in the process of subgroup formation. $^{4}$

Second, while the present study uses the relational attributes (e.g., gender) to divide a team into subgroups and calculate within-subgroup FLS, future researches could extend it to use the task-based attributes (e.g., tenure) to divide a team into subgroups and calculate within-group FLS to see if the results are similar or different. Beyond task-based attributes, other types of attributes (e.g., political beliefs and different preferences for risk-taking) may also create faultines on BODs.

Third, the empirical analyses are conducted using panel data derived from China characterized by various levels of environmental complexity, environmental dynamism, and environmental munificence. Therefore, results best generalize to that context. Future research may conduct replication studies in different contexts to see whether the results of the impact of gender FLS and its interaction with these environmental conditions on firm strategic change could be generalized to other settings. Future research could also collect multiple-country data to compare whether cross-country differences are present. 
Fourth, future research could consider other boundary conditions. For example, how does country culture influence the way gender faultlines on BODs unfold? Characteristics such as power distance or gender egalitarianism may influence the ways in which gender faultlines on BODs influence firm outcomes. There is much work to be done to understand the impact of BOD faultlines in not only the East but also the West. Moreover, in some countries like Norway, quotas have been mandated or highly recommended to increase the representation of women on BODs (Catalyst, 2014). For example, Norway, Spain, and France all require that $40 \%$ of board seats be held by women directors, and this is true for state-owned enterprises as well as publicly traded firms. Israel and the Québec province of Canada require 50\% of women on the BODs for state-owned enterprises, while Finland requires $40 \%$. Other examples include Iceland, which requires $40 \%$ of each gender be represented on boards, and Italy, which requires 33\% board membership for the gender that is underrepresented (Catalyst, 2014). Some quotas have been welcomed, while others have been met with resistance (Groysberg \& Chen, 2016). Does increasing the representation of women on boards through quotas make it more or less likely to create collaboration on boards where gender faultlines are present? Future research may answer this question.

Finally, our interaction effects are statistically significant but have mostly small effect sizes. Given our sample size $(N=5781)$, we ran additional analyses to test whether the interaction effects were driven by the large sample size. Thus, we narrowed the sample time window to years 2013-2015, and the sample size decreased from 5781 to 2867 . Then, we reran the model. The results are consistent with that of Table 2, and the three interactions are still statistically significant at the 5\% significance level. Specifically, coefficients of the three interactions are $.21(p=.000), 5.40(p=.027)$, and $1.00(p=.000)$, respectively. The effect sizes of three interactions are $.002, .006$, and .051 , respectively, which are larger than the previous results $(.001, .003$, and .042 , respectively) with the larger sample. This indicates that effect sizes get larger (even double) when we reduce the sample size. Compared to the other two interactions, the strongest effects were found for the BOD gender FLS $\times$ environmental munificence interaction, which explains a substantial amount of variance (4.2\%) for an interaction (McClelland \& Judd, 1993). Therefore, managers should pay particular attention to how much slack they have in their environment and how that influences the effects of gender FLS on strategic change. In summary, when the sample size is smaller, the effect sizes increased, and the statistical significance remained unchanged. Nevertheless, although the pattern of moderation is significant across the three moderators, we acknowledge that the effect size for the moderation of complexity and dynamism is modest relative to that of munificence. 


\section{Conclusion}

The BODs are quite possibly one of the most important types of teams in existence. Boards have been called the "supra top management team" (Finkelstein et al., 2009), a meta-analysis shows that boards have an impact on firm strategy (Deutsch, 2005), and another meta-analysis shows that female board representation positively influences strategic involvement (Post \& Byron, 2015). Decisions made at the upper echelons of organizations are very important because they can result in millions or billions (e.g., yen, US dollars, and euros) for the organization. Therefore, it behooves us to know when and under what conditions board characteristics are associated with the ability to be responsive to changing market conditions. The present study reveals that board gender FLS is negatively associated with strategic change, but under conditions of environmental complexity, environmental dynamism, and environmental munificence, when the faultline perspectives may be needed the most, this relationship is attenuated and becomes positive. We hope this comprehensive examination of gender FLS on boards and its impact on strategic change will be a step toward learning about faultlines and frictions in the BOD and strategic change.

\section{Acknowledgments}

We are grateful to Xinhe Zhang for her contributions to earlier versions of this article.

\section{Declaration of Conflicting Interests}

The author(s) declared no potential conflicts of interest with respect to the research, authorship, and/or publication of this article.

\section{Funding}

The author(s) received no financial support for the research, authorship, and/or publication of this article.

\section{ORCID iDs}

Jie Wu (D) https://orcid.org/0000-0002-4289-4204

Luman Yu (D) https://orcid.org/0000-0003-1940-4796

\section{Notes}

1. As explained in the measure of gender FLS, it consists of two factors: internal subgroup alignment (IA) and CGAI. Given that CGAI already captures a partial effect of gender heterogeneity, and the correlation between FLS and gender heterogeneity is high, and the results including and excluding gender 
heterogeneity are almost unchanged, we do not include gender heterogeneity in the analyses to avoid unnecessary multicollinearity. The results including gender heterogeneity are available upon request.

2. Due to the space consideration, the results including BOD heterogeneity variables are not reported in the main results but in the online supplement.

3. The results of these additional analyses can be found in the online supplement.

4. We thank an anonymous reviewer for this explanatory analogy.

\section{References}

2020 Women on Boards. (2017). Gender diversity index: 2017 key findings. Retrieved from https://www.2020wob.com/companies/2020-gender-diversity-index

Adams, R. B. (2016). Women on boards: The superheroes of tomorrow? The Leadership Quarterly, 27, 371-386.

Aiken, L. S., \& West, S. G. (1991). Multiple regression: Testing and interpreting interactions. Newbury Park, CA: Sage.

Andrevski G., Richard O. C., Shaw J. D., \& Ferrier W. J. (2014). Racial diversity and firm performance: The mediating role of competitive intensity. Journal of Management, 40(3), 820-844.

Atinc, G., \& Ocal, Y. (2014). The moderating effect of organizational environment on post-IPO corporate governance changes and firm performance relationship. Journal of Leadership \& Organizational Studies, 21(3), 286-298.

Baltagi, B. (2008). Econometric analysis of panel data. New York, NY: John Wiley \& Sons.

Barr, P. S., Stimpert, J. L., \& Huff, A. S. (1992). Cognitive change, strategic action, and organizational renewal. Strategic Management Journal, 13, 15-36.

Barron, D. N., West, E., \& Hannan, M. T. (1994). A time to grow and a time to die: Growth and mortality of credit unions in New York City, 1914-1990. American Journal of Sociology, 100(2), 381-421.

Bezrukova, K., Jehn, K. A., Zanutto, E. L., \& Thatcher, S. M. B. (2009). Do workgroup faultlines help or hurt? A moderated model of faultlines, team identification, and group performance. Organization Science, 20(1), 35-50.

Bezrukova, K., Thatcher, S. M., \& Jehn, K. A. (2007). Group heterogeneity and faultlines: Comparing alignment and dispersion theories of group composition. In K. J. Behfar \& L. L. Thompson (Eds.), Conflict in organizational groups: New directions in theory and practice (pp. 57-92). Evanston, IL: The Northwestern University Press.

Bloom, M., \& Michel, J. G. (2002). The relationships among organizational context, pay dispersion, and among managerial turnover. Academy of Management Journal, 45(1), 33-42.

Boone, C., Van Olffen, W., Van Witteloostuijn, A., \& de Brabander, B. (2004). The genesis of top management team diversity: Selective turnover among top management teams in dutch newspaper publishing, 1970-94. Academy of Management Journal, 47(5), 633-656.

Byrne, D. (1971). The attraction paradigm. New York: Academic Press. 
Catalyst. (2014). Legislative board diversity. Retrieved from http://www.catalyst.org/ legislative-board-diversity

Certo, S. T., \& Semadeni, M. (2006). Strategy research and panel data: Evidence and implications. Journal of Management, 32(3), 449-471.

Chadwick, C., Way, S. A., Kerr, G., \& Thacker, J. W. (2013). Boundary conditions of the high-investment human resource systems-small-firm labor productivity relationship. Personnel Psychology, 66(2), 311-343.

Choi, J. N., \& Sy, T. (2010). Group-level organizational citizenship behavior: Effects of demographic faultlines and conflict in small work groups. Journal of Organizational Behavior, 31(7), 1032-1054.

Chung, Y., Liao, H., Jackson, S. E., Subramony, M., Colakoglu, S., \& Jiang, Y. (2015). Cracking but not breaking: Joint effects of faultline strength and diversity climate on loyal behavior. Academy of Management Journal, 58(5), 1495-1515.

Cooper, D., Patel, P. C., \& Thatcher, S. M. B. (2014). It depends: Environmental context and the effects of faultlines on top management team performance. Organization Science, 25(2), 633-652.

Covin, J. G., \& Slevin, D. P. (1989). Strategic management of small firms in hostile and benign environments. Strategic Management Journal, 10(1), 75-87.

Cox, T. H., \& Blake, S. (1991). Managing cultural diversity: Implications for organizational competitiveness. Academy of Management Perspectives, 5(3), 45-56.

Cronin, M. A., Bezrukova, K., Weingart, L. R., \& Tinsley, C. H. (2011). Subgroups within a team: The role of cognitive and affective integration. Journal of Organizational Behavior, 32(6), 831-849.

Cumming, D., Leung, T. Y., \& Rui, O. (2015). Gender diversity and securities fraud. Academy of Management Journal, 58(5), 1572-1593.

Dervitsiotis, K. N. (2012). An innovation-based approach for coping with increasing complexity in the global economy. Total Quality Management \& Business Excellence, 23(9), 997-1011.

Dess, G. G., \& Beard, D. W. (1984). Dimensions of organizational task environments. Administrative Science Quarterly, 29, 52-73.

Deutsch, Y. (2005). The impact of board composition on firms' critical decisions: A meta-analytic review. Journal of Management, 31(3), 424-444.

Ferrier, W. J. (2001). Navigating the competitive landscape: The drivers and consequences of competitive aggressiveness. Academy of Management Journal, 44(4), 858-877.

Finkelstein, S., \& Hambrick, D. C. (1990). Top-management-team tenure and organizational outcomes: The moderating role of managerial discretion. Administrative Science Quarterly, 35, 484-503.

Finkelstein, S., Hambrick, D. C., \& Cannella, A. A. (2009). Strategic leadership: Theory and research on executives, top management teams, and boards. New York, NY: Oxford University Press.

Goll, I., \& Rasheed, A. M. A. (1997). Rational decision-making and firm performance: The moderating role of environment. Strategic Management Journal, 18, 583-591. 
Gordon, S. S., Stewart, W. H. Jr, Sweo, R., \& Luker, W. A. (2000). Convergence versus strategic reorientation: The antecedents of fast-paced organizational change. Journal of Management, 26(5), 911-945.

Greve, H. R. (2011). Positional rigidity: Low performance and resource acquisition in large and small firms. Strategic Management Journal, 32(1), 103-114.

Groysberg, B, \& Chen, Y. (2016). Global board of directors survey. Spencer Stuart and Women Corporate Directors Foundation. Retrieved from http://c.ymcdn.com/ sites/www.womencorporatedirectors.com/resource/resmgr/Knowledge_Bank/ WCDBoardSurvey2016_FINAL.pdf

Hambrick, D. C., \& Finkelstein, S. (1987). Managerial discretion: A bridge between polar views of organizational outcomes. Research in Organizational Behavior, 9, 369-406.

Hambrick, D. C., \& Mason, P. A. (1984). Upper echelons: The organization as a reflection of its top managers. Academy of Management Review, 9(2), 193-206.

Hannan, M. T., \& Freeman, J. (1984). Structural inertia and organizational change. American Sociological Review, 49, 149-164.

Harrison, D. A., \& Klein, K. J. (2007). What's the difference? Diversity constructs as separation, variety, or disparity in organizations. Academy of Management Review, 32(4), 1199-1228.

Hausman, J. A. (1978). Specification tests in econometrics. Econometrica: Journal of the Econometric Society, 46, 1251-1271.

Hitt, M. A., Hoskisson, R. E., Johnson, R. A., \& Moesel D. D. 1996). The market for corporate control and firm innovation. Academy of Management Journal, 39(5), 1084-1119.

Hofer, C. W., \& Schendel D. (1978). Strategy formulation: Analytical concepts. St. Paul, MN: West Publishing Company.

Jayaraman, N., Khorana, A., Nelling, E., \& Covin, J. (2000). CEO founder status and firm financial performance. Strategic Management Journal, 21, 1215-1224.

Jeong, S.-H., \& Harrison, D. A. (2017). Glass breaking, strategy making, and value creating: Meta-Analytic outcomes of women as CEOs and TMT members. Academy of Management Journal, 60(4), 1219-1252.

Kaczmarek, S., Kimino, S., \& Pye, A. (2012a). Board task-related faultlines and firm performance: A decade of evidence. Corporate Governance: An International Review, 20(4), 337-351. doi:10.1111/j.1467-8683.2011.00895.x

Kaczmarek, S., Kimino, S., \& Pye, A. (2012b). Antecedents of board composition: The role of nomination committees. Corporate Governance: An International Review, 20(5), 474-489. doi:10.1111/j.1467-8683.2012.00913.x

Karaevli, A. (2007). Performance consequences of new CEO 'outsiderness': Moderating effects of pre- and post-succession contexts. Strategic Management Journal, 28, 681-706.

Karau, S. J., \& Kelly, J. R. (1992). The effects of time scarcity and time abundance on group performance quality and interaction process. Journal of Experimental Social Psychology, 28, 542-571. 
Keats, B. W., \& Hitt, M. A. (1988). A causal model of linkages among environmental dimensions, macro organizational characteristics, and performance. Academy of Management Journal, 31(3), 570-598.

Kelly, J. R., \& Loving, T. J. (2004). Time pressure and group performance: Exploring underlying processes in the attentional focus model. Journal of Experimental Social Psychology, 40, 185-198.

Kraatz, M. S., \& Zajac, E. J. (2001). How organizational resources affect strategic change and performance in turbulent environments: Theory and evidence. Organization Science, 12, 632-657.

Lau, D. C., \& Murnighan, J. K. (1998). Demographic diversity and faultlines: The compositional dynamics of organizational groups. Academy of Management Review, 23(2), 325-340.

Lau, D. C., \& Murnighan, J. K. (2005). Interactions within groups and subgroups: The effects of demographic faultlines. Academy of Management Journal, 48(4), 645-659.

Li, J., \& Hambrick, D. C. (2005). Factional groups: A new vantage on demographic faultlines, conflict, and disintegration in work teams. Academy of Management Journal, 48(5), 794-813.

Lincoln, J. R., \& Miller, J. (1979). Work and friendship ties in organizations: A comparative analysis of relation networks. Administrative Science Quarterly, 24, 181-199.

Maume, D. J. Jr (2004). Is the glass ceiling a unique form of inequality? Evidence from a random-effects model of managerial attainment. Work and Occupations, 31(2), 250-274.

McClelland, G. H., \& Judd, C. M. (1993). Statistical difficulties of detecting interactions and moderator effects. Psychological Bulletin, 114(2), 376-390.

Menz, M. (2012). Functional top management team members: A review, synthesis, and research agenda. Journal of Management, 38(1), 45-80.

Messersmith, J. G., Lee, J.-Y., Guthrie, J. P., \& Ji, Y.-Y. (2014). Turnover at the top: Executive team departures and firm performance. Organization Science, 25(3), 776-793.

Meyer, B. \& Glenz, A. (2013). Team faultline measures: A computational comparison and a new approach to multiple subgroups. Organizational Research Methods, 16 , 393-424.

Miller C. C., Ogilvie, D. T., \& Glick, W. H. (2006). Assessing the external environment: An enrichment of the archival tradition. In D. J. Ketchen \& D. D. Bergh (Eds.), Research methodology in strategy and management (pp. 97-122). Bingley, UK: Emerald Group Publishing Limited.

Miller, D. (1991). Stale in the saddle: CEO tenure and the match between organization and environment. Management Science, 37(1), 34-52.

Milliken, F. J., \& Lant, T. K. (1991). The impact of an organization's recent performance history on strategic persistence and change: The role of managerial interpretations. In P. Shrivastava, A. Huff, \& J. Dutton (Eds.), Advances in strategic management (pp. 129-156). Greenwich, CT: JAI Press. 
Mitchell, W., Shaver, J. M., \& Yeung, B. (1992). Getting there in a global industry: Impacts on performance of changing international presence. Strategic Management Journal, 13, 419-432.

Morrison, A. M., White, R. P., \& Van Velsor, E. (1992). Breaking the glass ceiling: Can women reach the top of America's largest corporations? Reading, MA: AddisonWesley Publishing Co.

Nakauchi, M., \& Wiersema M. F. (2015). Executive succession and strategic change in Japan. Strategic Management Journal, 36(2), 298-306.

Nishii, L. H., Gotte, A., \& Raver, J. L. (2007). Upper echelon theory revisited: The relationship between upper echelon diversity, the adoption of diversity practices and organizational performance. CAHRS Working Paper Series. Cornell University.

Nyberg, A. J., \& Ployhart, R. E. (2013). Context-emergent turnover (CET) theory: A theory of collective turnover. Academy of Management Review, 38(1), 109-131.

Oehmichen, J., Schrapp S., \& Wolff, M. (2017). Who needs experts most? Board industry expertise and strategic change-a contingency perspective. Strategic Management Journal, 38(3), 645-656. doi:10.1002/smj.2513

Park, N. K., \& Mezias, J. M. (2005). Before and after the technology sector crash: The effect of environmental munificence on stock market response to alliances of ecommerce firms. Strategic Management Journal, 26, 987-1007.

Pathak, S., Hoskisson, R. E., \& Johnson, R. A. (2014). Settling up in CEO compensation: The impact of divestiture intensity and contextual factors in refocusing firms. Strategic Management Journal, 35(8), 1124-1143.

Polzer, J. T., Crisp, C. B., Jarvenpaa, S. L., \& Kim, J. W. (2006). Extending the faultline model to geographically dispersed teams: How collocated subgroups can impair group functioning. Academy of Management Journal, 49(4), 679-692.

Post, C., \& Byron, K. (2015). Women on boards and firm financial performance: A meta-analysis. Academy of Management Journal, 58(5), 1546-1571.

Richard, O. C., Murthi, B. P. S., \& Ismail, K. (2007). The impact of racial diversity on intermediate and long term performance: The moderating role of environmental context. Strategic Management Journal, 28, 1213-1233.

Richard, O. C., \& Shelor, R. M. (2002). Linking top management team age heterogeneity to firm performance: Juxtaposing two midrange theories. International Journal of Human Resource Management, 13, 958-974.

Richard, O. C., Wu, J., Markoczy, L. A., \& Chung, Y. (2019). Top management team demographic-faultline strength and strategic change: What role does environmental dynamism play? Strategic Management Journal, 40(6), 987-1009.

Savelsbergh, C., Gevers, J. M. P., van der Heijden, B. I. J. M., \& Poell, R. F. (2012). Team role stress: Relationships with team learning and performance in project teams. Group \& Organization Management, 37, 67-100.

Sawyer, J. E., Houlette, M. A., \& Yeagley, E. L. (2006). Decision performance and diversity structure: Comparing faultlines in convergent, crosscut, and racially homogeneous groups. Organizational Behavior and Human Decision Processes, 99(1), 1-15. 
Sharfman, M. P., \& Dean, J. W. (1991). Conceptualizing and measuring the organizational environment: A multidimensional approach. Journal of Management, 17(4), 681-700.

Shaw, J. B. (2004). The development and analysis of a measure of group faultlines. Organizational Research Methods, 7(1), 66-100.

Shepherd, D. A., Patzelt, H., \& Baron, R. A. (2013). "I care about nature, but ...": Disengaging values in assessing opportunities that cause harm. Academy of Management Journal, 56(5), 1251-1273.

Shi, W., Hoskisson, R. E., \& Zhang, Y. A. (2017). Independent director death and CEO acquisitiveness: Build an empire or pursue a quiet life? Strategic Management Journal, 38(3), 780-792.

Simons, T. L., \& Peterson, R. S. (2000). Task conflict and relationship conflict in top management teams: The pivotal role of intragroup trust. Journal of Applied Psychology, 85(1), 102.

Smith, N., \& Parrotta, P. (2018). Why so few women on boards of directors? Empirical evidence from Danish companies in 1998-2010. Journal of Business Ethics, 147, 445-467.

Staw, B. M., Sandelands, L. E., \& Dutton, J. E. (1981). Threat-rigidity effects in organizational behavior: A multilevel analysis. Administrative Science Quarterly, 26(4), 501-524.

Stewart, S. A. \& Amason, A. C. (2017). Assessing the State of Top Management Teams Research. Oxford Research Encyclopedia of Business and Management (pp. 1-24). Oxford University Press: New York.

Tabachnick, B. G., \& Fidell, L. S. (2001). Using multivariate statistics. Boston: Allyn \& Bacon.

Thatcher, S. M. B., Jehn, K. A., \& Zanutto, E. (2003). Cracks in diversity research: The effects of diversity faultlines on conflict and performance. Group Decision and Negotiation, 12(3), 217-241.

Thatcher, S. M. B., \& Patel, P. C. (2012). Group faultlines: A review, integration, and guide to future research. Journal of Management, 38(4), 969-1009.

Tinsley, C. H., Wade, J. B., Main, B. G. M., \& O’Reilly, C. A. (2017). Gender diversity on US corporate boards: Are we running in place? ILR Review, 70(1), 160-189.

Tirole, J. (1988). The theory of industrial organization. Cambridge, CA: MIT Press.

Triana, M. D. C., Miller, T. L., \& Trzebiatowski, T. M. (2014). The double-edged nature of board gender diversity: Diversity, firm performance, and the power of women directors as predictors of strategic change. Organization Science, 25(2), 609-632.

Tuggle, C. S., Schnatterly, K. \& Johnson, R. A. (2010). Attention patterns in the boardroom: How board composition and processes affect discussion of entrepreneurial issues. Academy of Management Journal, 53, 550-571.

Tung, R. L. (1979). Dimensions of organizational environments: An exploratory study of their impact on organizational structure. Academy of Management Journal, 22, 672-693. 
Van Dick, R., Van Knippenberg, D., Hägele, S., Guillaume, Y. R. F., \& Brodbeck, F. C. (2008). Group diversity and group identification: The moderating role of diversity beliefs. Human Relations, 61, 1463-1492.

Van Knippenberg, D. (2017). Team innovation. Annual Review of Organizational Psychology and Organizational Behavior, 4, 211-233.

Van Knippenberg, D., De Dreu, C. K. W., \& Homan, A. C. (2004). Work group diversity and group performance: An integrative model and research agenda. Journal of Applied Psychology, 89(6), 1008-1022.

Van Peteghem, M., Bruynseels, L., \& Gaeremynck, A. (2018). Beyond diversity: A tale of faultlines and frictions in the board of directors. The Accounting Review, 93(2), 339-367.

Wall Street Journal. (2012). In China and Hong Kong, women getting on boards. https:// blogs.wsj.com/chinarealtime/2012/08/02/in-china-and-hong-kong-women-getting-onboards/

Williams, K. Y., \& O’Reilly, C. (1998). Forty years of diversity research: A review. Research in Organizational Behavior, 20, 77-140.

Yamak, S., Nielsen, S., \& Escribá-Esteve, A. (2014). The role of external environment in upper echelons theory: A review of existing literature and future research directions. Group \& Organization Management, 39(1), 69-109.

Zajac, E. J., \& Kraatz, M. S. (1993). A diametric forces model of strategic change: Assessing the antecedents and consequences of restructuring in the higher education industry. Strategic Management Journal, 14, 83-102.

Zhang, Y. (2006). The presence of a separate COO/president and its impact on strategic change and CEO dismissal. Strategic Management Journal, 27(3), 283-300.

Associate Editor: William L. Gardner

Submitted Date: July 29, 2019

Revised Submission Date: January 5, 2021

Acceptance Date: January 7, 2021

\section{Author Biographies}

Jie Wu is the Chair Professor in Strategy and Entrepreneurship at the University of Aberdeen, United Kingdom. His research focuses on top management team faultline, culture and strategy, innovation and internationalization of emerging markets' firms, entrepreneurship etc. His work has appeared in the leading international business/ strategy, and interdisciplinary business management journals including: Strategic Management Journal, Journal of International Business Studies, Research Policy, Strategic Entrepreneurship Journal, Journal of World Business, Global Strategy Journal, and British Journal of Management, Journal of Business Ethics, International Journal of Research in Marketing, among others.

María del Carmen Triana is the Cal Turner Professor of Moral Leadership at Vanderbilt University in the Organization Studies area within the Owen Graduate School of Management. She earned a PhD in Organizational Behavior and Human 
Resources with a minor in Industrial/Organizational Psychology from Texas A\&M University. María's research interests include diversity and discrimination in organizations as well as diversity among strategic leaders.

Orlando C. Richard is the Dean's Research Professor in the Isenberg School of Management at the University of Massachusetts Amherst. He received his Ph.D. from the University of Kentucky before conducting post-doctoral research at Massachusetts Institute of Technology. His research interest includes diversity, inclusion, and equity issues in the workplace.

Luman $\mathbf{Y u}$ is a master student majored in Finance at University of Macau, Macau, China. He received his B. Eng from Tongji University, Shanghai, China. His research interest includes corporate social responsibility, corporate political activity, and corporate finance. 